Academic City University College - Accra Ghana

Society for Multidisciplinary \& Advanced Research Techniques (SMART) Africa

Tony Blair Institute for Global Change

FAIR Forward - Artificial Intelligence for All - Deutsche Gesellschaft für Internationale Zusammenarbeit (GIZ) GmbH

Accra Bespoke Multidisciplinary Innovations Conference (ABMIC)

\title{
The Almajiri Phenomenon in Northern Nigeria and the Rights of Children in Islam
}

\author{
Abdullahi Auwal \\ Department of Religious Studies \\ Gombe State University \\ Gombe, Gombe State, Nigeria \\ Email \\ auwalabdullahi48@gmail.com
}

Phone

$+2347038415852$

\section{Member Proceedings Citation Format}

Abdullahi A. (2021): The Almajiri Phenomenon in Northern Nigeria and the Rights

of Children in Islam. Proceedings of the Accra Bespoke Multidisciplinary Innovations

Conference. University of Ghana/Academic City University College, Accra, Ghana. December 2021. Pp 57-70 www.isteams.net/ghanabespoke2021.

DOI https://doi.org/ 10.22624/AIMS/ABMIC2021P5 


\title{
The Almajiri Phenomenon in Northern Nigeria and the Rights of Children in Islam
}

\author{
Abdullahi Auwal (PhD)
}

\begin{abstract}
Almajiri phenomenon which was once an approved and acceptable way to acquiring Islamic knowledge in the past has regrettably become a matter of sad concern for the North and the Nigerian nation. Children of school age roam about the streets in tattered clothes begging scavenging and doing all sorts of hard labour to earn a living. This paper examined the Almajiri Syndrome in Northern Nigeria and the rights of children in Islam. It is discovered that the present precarious condition which Almajiris are subjected to in many places in northern Nigeria, like poor accommodation, poor nutrition and health, education etc are not compatible with Islamic teachings with respects to rights of children. The paper therefore, suggested possible recommendations on how the problem of lumpen childhood upbringing can be rectified without compromising the genuine intent of seeking Islamic knowledge so as to produce Almajiris who will contribute to meaningful development of our nation. The paper inferred that, to safeguard the chastity of these children, parents must perform their duties diligently, government must provide proper legislations, enforce laws and provide adequate funding and community must help protect the rights of those children.
\end{abstract}

Keywords: Almajiri, Northern Nigeria, Islam, Rights, Children.

\section{INTRODUCTION}

The Almajiri practice is an old tradition that remains attractive to certain segments of people in northern Nigeria. Almajiri is a Hausa word derived from Arabic word 'Al-Muhajir' meaning emigrant (Kabiru, 2010). Almajiri (The plural of which in Hausa is Amajirai) refers to a person who left his home to attend an Islamic boarding school to learn Islamic knowledge (Sarkingobir et al, 2020) or migrates for the sake of propagating Islamic knowledge (Aghedo \& James, 2013). Almajiri abandoned his home for many months or years in the course of teaching or learning Islamic knowledge and other life experiences. Almajiri is a predominant system of Islamic education among Muslims in Northern Nigeria and other neighbouring countries like Niger Republic, Chad, Ghana, etc. It is an ancient practice and has been successful over the years especially during pre-colonial times with the support of government and wealthy people (Sarkingobir et al, 2020).

In fact, the almajiri system produced eminent jurists, Islamic scholars and religious reformers in the past (Aghedo \& James, 2013). Every year, usually after harvest, people inhabiting a particular neighborhood would gather their children, mostly school-age males (from age six upward), and hand them to an Islamic scholar (mallam) who is responsible for teaching the children the basics of Islam and how to write and recite the Arabic alphabet (Oladosu, 2012). In order to escape the distractions of life, the mallam would take the Almajirai out of the city to a camp where they were taught self-reliance as well as discipline. 
Sometimes, when there was shortage of food, the Quranic teacher would send the pupils out to solicit for food from residents around and the food would be brought back to the camp for all to eat. This practice of soliciting for food by the Almajirai became known as "Almajiranchi"-a practice meant to make them strong and to prepare them for life's struggle (Aghedo \& James, 2013).

During colonization, the British invaded the region and truncated the system of leadership where emirs have the authoritative powers to rule relegating them to mere traditional rulers that have no constitutional powers. This is the genesis of the predicament of the Almajiri system today which rendered Almajiris together with their Mallams, having no financial support resorted to begging and other menial jobs for survival (Abdul Qadir, 2003; Taiwo, 2012). Nowadays, because of shift of consciousness to the western education, the government and people left the system to languish.The Almajiri schools are now in deplorable conditions, likewise the teachers and students (Almajiri). Hence begging became the order of the day. This was not meant to be as Islam frowns at begging in any form because it reduces a Muslim's self-esteem and dignity. Yet parents release their children to undergo this horrific condition out of poverty. Children of five and above years are allowed to seek for living and study through begging and other forms of labour.

It is therefore imperative to study the condition of Almajiri as social phenomena and relate it with basic Islamic rights of a child in Islam to check the conformity and compatibility or otherwise of the system with Islamic provisions to provide a clear view of Islamic disposition on children and their God-given rights in Islam.

\section{ALMAJIRI PHENOMENON IN NORTHERN NIGERIA}

Northern Nigeria is a geo-political zone that comprises of 19 states which are predominantly Muslims and the FCT. A recent report has it that, there are more than 10 million Almajiris on the streets of northern Nigeria, without formal education and invariably going to face a bleak future (Taiwo, 2014). These children are out-of-school children roaming about streets begging for alms and food in motor parks, restaurants, fueling stations etc. Some Almajiris do not know their homes or who their parents are as they are left early in life (Taiwo, 2014). They are also denied of years of constant emotional and physical contact with their families, which affect them psychologically; leaving them at the mercy of the negative minds of the society (Muhammad, 2015; Sarkingobir et al., 2019).

This group of children is normally under a teacher (mallam) who is vast in the Islamic knowledge. In most cases, the population of these children is large and their mallam will have no option than to send them out to beg for what to eat, not caring about the nature of the food: cooked, fresh or stale which can be picked from anywhere as they do scavenge in filthy places (Taiwo, 2014). From their appearance too they rarely take their bath. It is surprising however to see that they rarely fall sick. Kabiru (2012) quoted Abdulkareem Kwando a medical doctor as saying that, 'the condition under which these street urchins lives makes them to develop very strong immunity to illnesses and diseases, which baffle medical practitioners.' (Taiwo, 2014) Almajiris are left without means or ability to obtain basic necessities of life such as food water, shelter, clothing, hygiene, healthcare etc. The consequences are seen in their deplorable conditions .They are ubiquitous in our streets, markets, houses, garages etc wandering in dirty clothes and ugly display in search for livelihood. 
This is not unconnected with negligence by the governments, parents, wards, and the entire society (Otu, 1992; Nigeria Research Network, 2013; Muhammad, 2015; Kankara, 2016). In addition to all these predicaments, they are also abused sexually. The abuse, in most cases remaine undisclosed because of fear. When it is disclosed, it happened as a process, not as an event (Lipppert et al., 2009; Priebe, 2009; International Rescue Committee, 2012; Townsend and Rheingold, 2013; WHO, 2015; Greijer, 2016).

These compounded challenges confronting the fragile and vulnerable almajiri affect his physical and mental health resulting into harmful behaviours, suicide, depression, physical injuries stimulate drug abuse, sexually transmitted infections. It also causes stigmatization, discrimination, and traumatisation of the victim or his upcoming progenies (Taiwo, 2014). Despite the establishment of Tsangaya Schools during President Good luck Jonathan Regime (2009-2015) and some state governments' interventions in modernizing the Tsangaya System which is the frame work for Almajiri process, Taiwo, 2014 opined that the government and people of the north are not doing their best to curtail the problem.

\section{THE RIGHTS CHILDREN IN ISLAM}

\subsection{Introduction}

Islam as a complete religion has not left a single matter without setting Sharia-based, ethical, humanitarian and spiritual rules that complement the edifice of man, who is God's vicegerent on earth. Children are gifts and awards from the Almighty Allah; they are a trust in our custody. We must therefore care well for them and preserve them by implementing the teachings of Islam; Our Noble Prophet (SAW) has guided us in his pure tradition, where he said:

"Each of you is a shepherd, and each of you is accountable for his or her flock"

In its legislation and jurisprudential laws, Islam pays special attention to children and childhood. Jurists and scholars in Islam agree that the Islamic Sharia is aimed at accomplishing five objectives or purposes for humanity. These are: Safeguarding progeny, life, sanity, property and faith. These five sublime objectives of Islamic shari'ah are essentials or fundamentals, without which life may not be possible. When any of these fundamentals is undermined, life will be compromised and may become chaotic. Consequently, humanity will suffer in this life and in the Hereafter.

\subsection{Important Phases of Child Development in Islam}

It would suffice to point to the rigorous legislation dealing with the child from the early days of formation in the womb of the mother, all the way until he or she attains the age of puberty or even beyond. In between, there are the various stages of pregnancy, birth, breastfeeding, weaning, playfulness, discipline and education, friendliness and companionship, and finally independence and self-reliance.

After birth, the stages of child development can be divided into the following according to physical and mental capability of the child:
i. Play
ii. Discipline
iii. Companionship

It was reported from Aliy Ibn Abi Talib who said: 
"Play with the child for seven years; discipline him (or her) for seven years; accompany him (or her) for seven years; and then release him (or her) to lead his (or her) own life."

Throughout these stages, the child is attended to by rules, laws and guidelines that altogether cover the child's upbringing and the rights that parents, the family and society need to protect. Islam pays special attention to equality between male and female newborns. It prohibits discrimination among children when it comes to care and attention, or to endowing them with gifts, grants or prizes.

\subsection{The Right of Child to Healthcare and Proper Nutrition}

Healthcare for a child begins with conception inside the womb. Islam provides protection for the fetus. Sharia makes it incumbent upon the husband to sustain the mother and the child and to increase her share of food and drink so as to remain healthy. It is his duty as well to provide her with psychological care. This is in direct compliance with the saying of the Messenger (SAW):

"Allah will (on the Day of Reckoning) question each person in a position of responsibility about what he (she) was responsible for (in this life)". (Sunan At-Tirmidhi, 4/208).

After birth, the child is entitled to proper breastfeeding for proper nutrition. Allah says:

"The mothers shall give suck to their children for two whole years, (that is) for those (parents) who desire to complete the term of suckling, but the father of the child shall bear the cost of the mother's food and clothing on a reasonable basis. No person shall have a burden laid on him greater than he can bear. No mother shall be treated unfairly on account of her child, nor father on account of his child. And on the (father's) heir is incumbent the like of that (which was incumbent on the father). If they both decide on weaning, by mutual consent, and after due consultation, there is no sin on them. And if you decide on a foster suckling-mother for your children, there is no sin on you, provided you pay (the mother) what you agreed (to give her) on reasonable basis. And fear Allah and know that Allah is All-Seer of what you do. (Al-Baqara, verse 233)

To further protect fetus from harm or hardship Islam has given a pregnant woman the right not to fast during the month of Ramadan, should she be concerned that such fasting might harm her fetus (Ahmad, et al, 2005). When the child is strong enough and has past the nursing stage, and since he or she requires body-building nutrition that is appropriate for each age, his or her parents must satisfy the child's right to be appropriately fed as he or she grows older and bigger.

It is also the parents' duty to attend to any medical needs the child may have as a result of illness. They must take every precaution and protective measure to prevent the child from falling ill. Child vaccinations mandated at the times they are supposed to be taken should not be taken lightly. Neglecting such a responsibility would amount to a grave sin for which the parent is accountable before Allah, the Lord of All Creations. Allah says:

"...and do not throw yourselves into destruction [by not spending your wealth in the cause of Allah], and do good, truly, Allah loves Al-Muhsinun [the good-doers]. (Al-Baqara, verse 195). 
Looking at this fundamental right of children to proper health and nutrition, the forsaken Almajiris don't enjoy this right. When a father as a head of a family send his child to a far places some hundreds of kilometers away from him and rarely visits the child nor provide mallam with resources to take care of food and healthcare of that child, then he is not living up to his responsibilities and will definitely be questioned on the day of resurrection on this.

Begging for food or scavenging to get what to eat will never provide his child with good and hygienic food for survival.

\subsection{The Right of the Child to Education and the Acquisition of Skills}

Once the child reaches the age of comprehending and learning, he or she has the right to be provided by his or her parents with knowledge to develop intellectual capabilities that enable the child to recognize and learn to deal with the various surrounding aspects of life. This helps the child realize that he or she is part of this collectivity, and cannot live in isolation. Since the seeking of knowledge is a religious duty in Islam, parents are expected to perform this duty by providing education to their children as they take their first steps in life. Any negligence in initiating this process means compromising their responsibility, with the consequence of further negligence in the subsequent stages of the lives of their children. Once the foundation is lost, nothing remains on which to build a sound edifice.

The holy prophet saw said:

One who is made the guardian of more or less children, will be questioned by Allah Ta'ala on the day of Judgement whether his subordinates followed the path of Islam, or he ruined them?".

A guardian or parent is pressed by the Sharia to adequately provide for their children or wards with knowledge which is not only for hereafter but also for this life. The prophet saw said:

"One, who is bestowed with children by the Almighty Allah, should give them good names, fine training and education and get them married when they gain adulthood. In case if they are not married and transgress the limits of virtue, the father will be held responsible"

The principles of Islamic Sharia offer males and females equal opportunities in education; this should be granted serious consideration. In a Hadith, the Prophet (SAW) said:

"The seeking of knowledge is obligatory upon every Muslim male and Muslim female"

The attention of Islam and the Muslims to learning goes beyond the spending of effort and money. Individuals are encouraged to acquire knowledge wherever it may be.

The Prophet of Islam said:

"Knowledge comes only through learning." He also said: "Facilitate things for the people (treat them in the most agreeable way); do not make things difficult for them; give them glad tidings and do not repulse them." (Al-Bukhari 1/62)

\section{Allah Ta'ala Says:}

"Say are those who know equal to those who know not? It is only men of understanding who will remember [i.e., get a lesson from Allah's signs and verses] (Az-Zummar, verse 9) He also says: 
Allah will exalt in degree those of you who believe, and those who have been granted knowledge. And Allah is well-acquainted with what you do. (Al-Mujadalah, verse 11). He also says:

It is only those who have knowledge among his slaves who fear Allah. (Fatir, verse 28)

The Prophet (SAW) said:

"Humans are either teachers or learners. There is nothing good beyond that". (Sunan Al-Darimi Hadith 246).

Almajiri is attributed to search for Islamic knowledge; this is quite a good course. But have the parents, the community and government provided the system with all what is required to function well? How many hours do the Almajiris dedicate for learning? Are parents sponsoring the mallams that sacrifice much for the children? All these should call for investigation and monitoring. If the answers are found to be negative then, the God-given right of the children to acquire education is abused, and whoever is responsible for their care will be interrogated on the day of reckoning on their failure to handle responsibilities that rest on their shoulders.

\subsection{The Right of the Child to Lead a Dignified and Secured Life}

The Islamic Sharia prescribes that the financial requirements of the young children are the responsibility of the father, so as to guarantee they are being cared for and are safe.

The Almighty Allah says:

"But the father of the child shall bear the cost of the mother's food and clothing on a reasonable basis" (Al-Baqara, Verse 233).

He also says:

Let the rich man spend according to his means; and the man whose resources are restricted, let him spend according to what Allah has given him. Allah puts no burden on any person beyond what he has given him. Allah will grant after hardship, ease. (AlTalaq, verse 7)

In a case where the father who has the responsibility to feed his family fail to do so despite having all the provisions, the Prophet (SAW) said to the woman who asked him about how much she was entitled to take from her miser husband without his knowledge:

"Take in a seemly manner what suffices for you and your children."(Al-Bukhari 2/416).

This Hadith explains the amount of what may be considered adequate nafaqah (financial support) for the wife and the children. The amount is linked to ability and adequacy, and would vary depending on availability.

Reaching the age of puberty and acquiring the ability to make a living would constitute a reason for terminating financial support. This would mean that the father has a responsibility to educate the child and train him or her to sustain him or herself without needing the father's subsidy. In case the father dies, leaving behind children with insufficient funds in his will, then the mother and other heirs have an obligation to provide for these children. The Almighty Allah says in the Qur'an:

"And on the [father's] heir is incumbent the like of that [which was incumbent on the father]". (Al-Baqara, Verse 233) 
The rule is that, every obligation incumbent upon the deceased during his life is incumbent upon his or her heirs after his death. This Qur'anic verse provides decisive evidence of the fairness of the Islamic law of inheritance. By taking delivery of inheritance, the heir does not, in any way, relinquish his or her responsibilities towards those who had been under the care of the person from whom he or she has inherited. An heir has a duty to provide care and education to those who are still in need of such essential services. This is an example of how Islam enjoins compassion and encourages individuals to be grateful (Ahmad et al, 2015).

The child has a right to be trained by his or her parents to perform religious rituals. The importance of early training is that it allows religious practice to become an easy and acceptable habit that children will maintain and preserve. The parents should endeavour to be role models for their children in terms of adhering to the best of conduct. They also have the obligation to provide their children with love, kindness and mercy, and to avoid harshness and cruelty. The is also a saying that goes:

"May Allah have mercy on a parent who helps his or her child to be good to him or her."

Universal principles have called for recognizing the rights of all children without discrimination. The Islamic Sharia, in its own way, has affirmed these rights in terms of Qur'anic and Prophetic directives. The Almighty Allah says:

O mankind! We have created you from a male and a female, and made you into nations and tribes, that you may know One another. Verily, the most honourable of you with Allah is that [believer] who has At-taqwa [piety] (i.e., he is one of the Muttaqun [the pious]). Verily, Allah is All-knowing, All-aware. (Al-Hujurat, Verse 13)

He also says:

The believers are nothing else than brothers [in Islamic religion]. (Al-Hujurat, verse 10)

The Islamic Sharia has also prescribed equality as a general principle for the Islamic state, in which no preference is made except in terms of righteousness; a child deprived of parental care should be sponsored. His or her sponsors should act as if they are the child's parents, and are expected to provide what parents are usually expected to provide. The Islamic Sharia encourages Muslims to take up sponsorship to provide care for children in need. In compensating for the loss of parental care, the sponsors are promised a great reward; they will be in the company of the Prophet himself in Paradise. The Prophet (SAW) said:

"I shall be in Paradise together with the sponsor of the orphan just as these two are"

And he pointed to his index and middle finger. There should be no discrimination between an orphan whose father is known and an orphan without known ancestry. The right of the child to a family, kindred, name, property and inheritance are all part of children's right in Islam that relates to their social security and dignity. Kindred bonds are relations of one man with other men who are blood relatives. The family is the receptacle of kindred. Family ties together with their social, psychological, economic support and needed for a child to develop. Forsaking your responsibility as a parent by sending your child or ward for Almajiranci without due recourse to his safety, security, health and hygiene, chastity, etc is a gross negligence to Islamic teachings on the rights of children and parents must take full responsibility of their "sin" on the day or resurrection. 


\subsubsection{Hard Labor}

Exploiting children (whether Almajiri or not) in arduous or dangerous jobs is not permissible in Islam. Any job capable of causing damage to the health of children, exposing them to danger or too difficult for them to undertake is a hard labor and Islam has protected them from such. The Islamic Sharia charges the father with the responsibility of providing maintenance for his children. Allah's Messenger (SAW) said: "The best money spent by a man is the money he spends on his children." (Muslim, 2/691-692, Hadith 994).

Working to provide maintenance for children has even been made a cause for the atonement of sins. It has been reported that: "There are sins that can be atoned by nothing apart from toiling to earn a living." (Majma' Al-Zawa'id, 4/63-64).

Employing children in hard and dangerous labour would fall into the category of inflicting hardship and harm on them Sharia does not expect humans to undertake arduous tasks, as is clearly manifest in the Qur'anic verse:

“...And has not laid upon you in religion any hardship... (Al-Hajj, Verse 78)

The Almighty Allah also says:

"Allah intends for you ease, and he does not want to make things difficult for you. (AlBaqarah, verse 185)

He also says:

“Allah burdens not a person beyond his scope... (Al-Baqarah, verse 286)

If Allah has willed that no hardship should be suffered because of what He commands, it follows that humans are forbidden from inflicting hardship on one another. If inflicting hardship on adults is forbidden, it goes without saying that inflicting hardship on youngsters is also forbidden. Children at this age must be treated with kindness and compassion at school. Allah's Messenger (SAW) said to A'ishah:

"O A'ishah! Kindness will invariably make things more beautiful while its lack will make them ugly." (Ahmad et al, 2005).

\subsubsection{Corporal punishment}

Many researches and reports by human right activist and other organisations have pointed out and frowned at the kind of punishment meted out to Almajiris as cruel. It is indeed un-islamic to flog a child severely as this may cause physical injury and psychological trauma. In the Islamic shari'ah, beating is not completely discarded as a method of punishment but it is surrounded by conditions to protect the child from harm. The prophet saw was reported to have said:

"Order your children to perform salah when they are seven of age; beat them upon not performing it when they are ten years old". (Sunan Abu Dawud, 495)

Islam has defined the punishment limit with and outlined conditions to protect the child from social, physical, or psychological harm. The prophet saw never raise his hand on Anas bin Malik, his minor. Therefore, flogging should be the last resort and should be done without inflicting harm to the child. 


\section{LEVELS OF RESPONSIBILITIES REGARDS TO CHILDREN RIGHTS IN ISLAM}

For the purpose of this paper, three levels of responsibility are identified with respect to caring and protecting the rights of children:

\section{Parents}

Parental care is the main foundation for providing protection for children and enabling them to enjoy the rights guaranteed by Islam. Parents are the fist category saddled with the responsibility of taking care of their children, protecting them and providing them with all their needs to preserve their religion, social life, physical and mental health etc.

\section{Allah says:}

"O you who believe! Ward off yourselves and your families against a Fire (Hell) whose fuel is men and stones, over which are (appointed) angels stem (and) severe, who disobey not, (from executing) the Commands they receive from Allah, but do that which they are commanded" (Tahrim, verse 6).

Whether at home or elsewhere, parents are responsible for preserving the life, health, safety, chastity etc of their children or wards. Parents love, care, kindness etc are what the child needs to develop. They are the first set of teachers, health personnel, psychologists, counselors and social workers to their children. When they are send out for almajiranci or any form of endevour approved by Islam, they should be under care, and custody of a trustworthy person that can provide all these needs to them, otherwise their rights are tempered with and Allah is All-seeing All-knowing.

\section{Immediate Muslim Community}

When children grow up, they go out of their homes and mingle with their peers, interact with other Muslims, neighbors and immediate community. Individually, every Muslim has the responsibility of taking care of another Muslim and protecting his right. He should not do what harm another Muslims and if he sees him in danger it is his responsibility to try his best in saving him from that danger or harm as the prophet saw said:

"Whosoever of you sees an evil, let him change it with his hand; and if he is not able to do so, then [let him change it] with his tongue; and if he is not able to do so, then with his heart - and that is the weakest of faith." (Muslim)

And he also said:

"Each of you is a shepherd, and each of you is accountable for his or her flock". "Allah will (on the Day of Reckoning) question each person in a position of responsibility about what he (or she) was responsible for (in this life)."

In addition, the payment of obligatory Zakat (alms) and charitable donations by members and foundations within the society secures substantial amounts of money to fund projects in education, health, social welfare for destitute children, orphans and poor families Almajiris inclusive.

“...and do not throw yourselves into destruction [by not Spending your wealth in the cause of Allah], and do good. Truly, Allah loves Al-muhsinun [the good-doers]. (Al-Baqara, verse 195) 
The Noble Prophet SAW said:

"Whoever fulfilled the needs of his brother, Allah will fulfil his needs; whoever brought his (Muslim) brother out of discomfort, Allah will bring him out of the discomforts of the Day of Resurrection, and whoever shielded a Muslim (from shame or scandal), Allah will shield him on the Day of Resurrection." (Al-Bukari, 4/1996, Hadith 2580).

\section{The Government or the Institutions of the State}

Government or State institutions have a role in this regard that is no less important. For all children to enjoy their rights without discrimination, it is a prerequisite that the state constitution should unequivocally state that children have rights to a name, an identity, property and inheritance, sponsorship in a family, health care and education.

Of no less importance is a legislature's responsibility to pass laws guaranteeing the protection of children from exploitation in harsh or dangerous jobs, or in activities that may render them liable before the law, or that may constitute physical or moral humiliation for them.

\section{CONCLUSION}

The present condition of Almajiri in northern Nigeria is a piety and a total negation to the Islamic teachings and principles. Islam gives children the rights to health and be nurtured in a very good environment and manner. They have the right to be educated in a socially acceptable fashion.

The Messenger SAW said:

"Honour your children and give them good names." He also said: "He is not one of us who does not show mercy to our youngsters." He also said: "He who does not show mercy will be shown no mercy (on the Day of Judgment)."

Honouring children encompasses proper upbringing to protect their souls and body from harm of whatever kind which may affect their spiritual, social or physical well-being in the society. It is also necessary to protect children and do all we can to help them grow up in a healthy and clean environment that is free from disease and pollution. Attending to children's personal hygiene and physical health will turn them into healthy and strong individuals who are able to receive learning and acquire knowledge. Therefore, we must all join forces and combine efforts in order to bring to the human being all that is good and beneficial, in observance of Allah's commandment in the Noble Book, where he says:

"Cooperate in that which is righteous and conducive to piety and do not cooperate in that which is sinful and conducive to aggression" (Al-Qur'an)

It would follow therefore; that whoever violates one of the rights of children, who are tomorrow's men and women, and the hope of each nation as its future leaders, disobeys Allah and contravenes the lofty Sharia therefore has committed a sin in Islam. It is the responsibility of parents, community and government to cater for and protect children especially Almajiris from any form of child abuse which contravenes Islamic teachings. 


\section{RECOMMENDATIONS}

From the discussion made, the following recommendations are very relevant towards improving the life Almajiri in Northern Nigeria:

1. Parents should be enlightened through every means possible to live up to expectations in discharging their duties upon their children. They shouldn't be running away from their God-ordained responsibilities.

2. The family and society should work simultaneously in combating the worst kinds of child employment, and in protecting vulnerable children by providing them with the necessary parental care in a cohesive family. Children are trusts that should not be abandoned at any time. Families must reject financial incentives linked to these delinquent practices.

3. There is a pressing need for the preparation of special programmes to educate children and young men and women so as to be alert to resisting those who try to lure them into risky situations. They should be warned against the repercussions and urged not to hesitate to report any dubious attempts made in this regard.

4. The state has a major role to play in legislating heavy penalties for those found guilty of luring children into dubious affairs. Criminals should be deterred from destroying the lives and future of these children.

5. Governments should allocate sufficient funds to implement programmes to protect children deprived of parental care and re-integrate them into society. Such children are the most vulnerable to the worst forms of exploitation.

6. Of further importance is the ratification of international treaties that organize cooperation among nations to combat the sale or trafficking of children across borders for the purpose of exploiting them sexually. The treaties allow for the organized repatriation of trafficked children and for the provision of health care and education wherever these children happen to be. 


\section{REFERENCES}

1. Abdillah bin Abd Al-Rahman Al-Darimiy(n.d.), Sunan Al-Darimiy. Dar Al-Zayat for heritage.

2. Abdul Qadir I. A. (2003). The Almajiri System of Education in Nigeria Today. Presention at the 21st Convocation of Bayero University Kano. www,gamji.com/index.php/SJPAS/article/view/637

3. Abu Dawud (n.d.). Sunan Abu Dawud. Al-Dar Al-Hadithah Edition, Cairo.

4. Aghedo I. \& James, S.E. (2013). From Alms to Arms: The Almajiri Phenomenon and Internal Security in Northern Nigeria, The Korean Journal of Policy Studies, Vol. 28, No. 3 (2013), pp. 97-123.

5. Ahmad, R. A., Aminah M. N., Gamal, A. A., Sahar, A., Taha, A. K., Adil, M. A., Ablah, A., Ali, I., Omar, A., Muhammad R. U., Mahmud T. (2005). Children in Islam: Their Care, Upbringing and Protection, Al-Azhar University in cooperation with the United Nations Children's Fund (UNICEF)

6. Al-Qur'anil Kareem, (1996). English Translation by Mushin Khan, M. \& Al-Hilali, M. T. Interpretation of the meaning of the Noble Qur'an from Arabic to English Language, Riyad: Darus-Salam Publishers \& Distributors.

7. Amzat, J. (2008). Lumpen Childhood in Nigeria: A Case of the Almajirai in Northern Nigeria, Hemispheres No. 23, (2008) PL ISSN 0239-8818

8. At-Tirmidhi, M. I. (2006) Al-Sunan, Beirut: Darel-Kutub Ilmiyyah.

9. Bukharīi, M. I. (1966). Sahih Bukhari. English Translation by Muhammad Sarid.

10. Greijer, S.(2016). Terminology for the Protection of Children from Sexual Exploitation and Sexual Abuse, Adopted by the Interagency Working Group in Luxemburg www.ecpat.net. Hausa. knotted.com/labaren-hausa.

11. Ibn Hanbal, A. (n.d) Musnad Ahmad bn Hanbal, Beirut: Maktabah Al-Islami

12. International Rescue Committee ( 2012). Caring for child survivors of sexual abuse b: guidelines for health and psychological services providers. 1st edition .IRC Agency Headquarters, 1222 East 42nd Street, Newyork, USA.

13. Kabiru, I. (2010). The North and Almajiri Phenomenon. www.gamji.com/article8000/NEWS8282.htm.

14. Kankara, A.I. (2016). Opinion : the Almajiri and comfort of a learning. www.ynaija.com

15. Lippert, T., Cross T. P., Jones L. ( 2009). Telling interviewers about sexual abuse : predictors of childndisclosure at forensic interviews .Child Maltreatment,14(1): 100113.

16. Majma' Al-Zawa'id wa Manba' Al-Fawa'id. By Al-Imam Nuruddin Ali bin Abu

17. Muhammad ,F.(2015). Prevalence of Child Abuse Among Pupils in Almajiri System of Education in Zaria Local Government, Kaduna State , Nigeria. Masters thesis submitted at University of Nigeria, Enugu.

18. Muslim, H. M. (2009) Sahih Muslim. English Translation by Abd-al-Hamid Siddiqui

19. Nigeria Research Network (2013). Almajiri in Birth Nigeria: a collective responsibility

20. Oladosu, A. G. A. S. 2012. Arabic and Islamic education in Nigeria: The case of Al- Majiri schools. World Academy of Science, Engineering and Technology, 71: 1820-1824.

21. Otu, J. (1992).nPortrait of the Almajiri: a study of their daily activities in painting. Master's Thesis submitted at ABU, Zaria. Our End Violence Against Women and their Children (2014). Reporting on child sexual abuse.

22. Priebe, G. (2009). Adolescents Experiences of Sexual Abuse: Prevalence ,Abuse Characteristics, Disclosure, Health and Ethical Aspects. Lund University, Faculty of Medicine. 
23. Sarkingobir Y., Sambo S., Hamza A., Tambari U., Sahabi M., Salau I.A. (2020). An Almajiri Student in the Northern Nigeria: The Neglected Vulnerable For Sexual Abuse (Rape). Int. J. Polit. Sci. Develop. 8(1) 15-20

24. Taiwo, F. J. (2014). Transforming the Almajiri Education for the Benefit of the Nigerian Society, International Letters of Social and Humanistic Sciences Online, Vol. 19, pp 244251 doi:10.18052/www.scipress.com/ILSHS.19.244

25. Townsend, C, Rheingold, A.A. ( 2013). A review of Child Sexual Abuse Prevalence Studies Charleston S.C, Darkness to Light. Retrieved from wwww.D2L.org/lin10.

26. World Health Organisation (2015). Men who have sex with mean. A technical brief. WHO Geneva, Switzerland. 